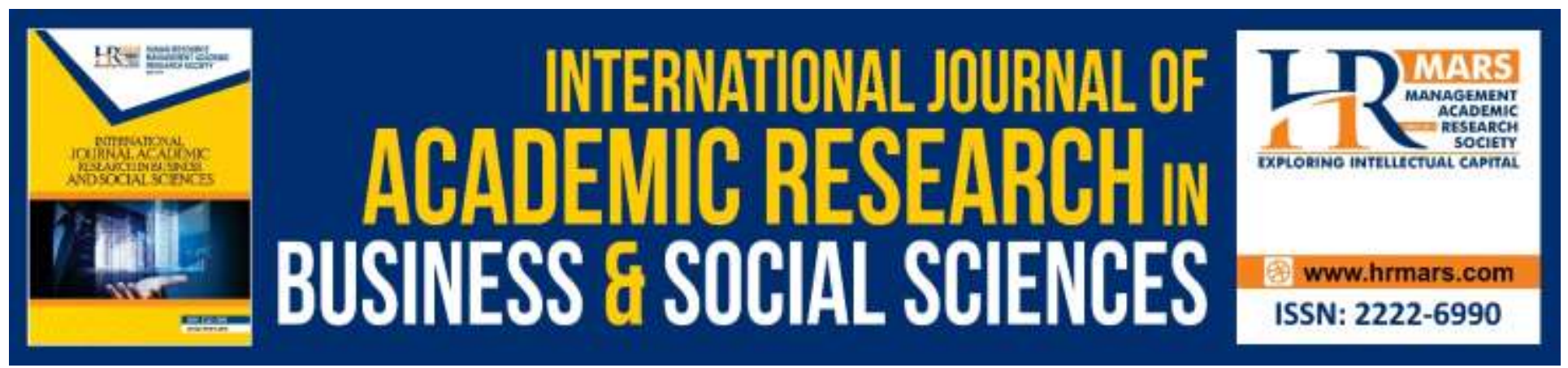

\title{
Surviving through Politics in Organization? A Study on Employees within MNCS in Malaysia
}

Melissa Wee, Amira Afiqa Jasni, Heri Yanto, Mohd Zaki Sadik

To Link this Article: http://dx.doi.org/10.6007/IJARBSS/v10-i3/7038

DOI:10.6007/IJARBSS/v10-i3/7038

Received: 01 February 2020, Revised: 22 February 2020, Accepted: 12 March 2020

Published Online: 28 March 2020

In-Text Citation: (Wee et al., 2020)

To Cite this Article: Wee, M., Jasni, A. A., Yanto, H., \& Sadik, M. Z. (2020). Surviving through Politics in

Organization? A Study on Employees within MNCS in Malaysia. International Journal of Academic Research

in Business and Social Sciences, 10(3), 202-208.

Copyright: (C) 2020 The Author(s)

Published by Human Resource Management Academic Research Society (www.hrmars.com)

This article is published under the Creative Commons Attribution (CC BY 4.0) license. Anyone may reproduce, distribute, translate and create derivative works of this article (for both commercial and non-commercial purposes), subject to full attribution to the original publication and authors. The full terms of this license may be seen

at: http://creativecommons.org/licences/by/4.0/legalcode

\section{Vol. 10, No. 3, 2020, Pg. 202 - 208}

Full Terms \& Conditions of access and use can be found at http://hrmars.com/index.php/pages/detail/publication-ethics 


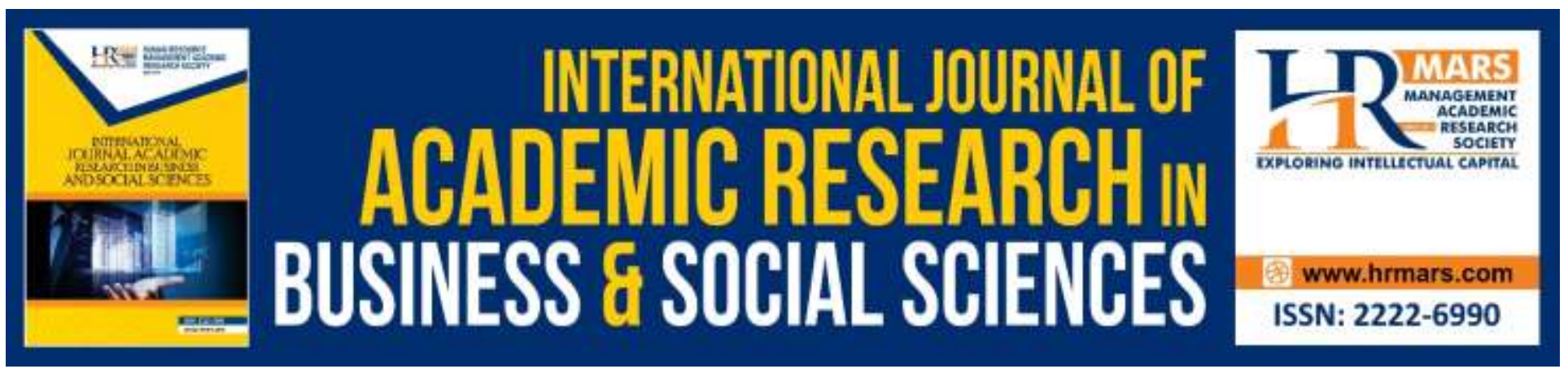

\title{
Surviving through Politics in Organization? A Study on Employees within MNCS in Malaysia
}

\author{
Melissa Wee, Amira Afiqa Jasni, Heri Yanto, Mohd Zaki Sadik \\ Faculty of Business Management, Universiti Teknologi Mara Melaka, Faculty of Economics, \\ Universitas Negeri Semarang, Semarang, Indonesia
}

\begin{abstract}
This research looks into the roles of political skill towards multinational corporations (MNCs) stakeholders' perspectives. A cross sectional and quantitative study were conducted to a total of 85 respondents through a judgemental purposive sampling from selected employees working in MNCs. The dimensions of political skill are four which consists of social astuteness, interpersonal influence, apparent sincerity and networking ability. Results of this study indicated that there are positive relationships between interpersonal influence and apparent sincerity with stakeholders' satisfaction within the MNCS
\end{abstract}

Keyword: Political skill, Social Astuteness, Networking Ability, Interpersonal Influence, Apparent Sincerity, Stakeholder

\section{Introduction}

There is a strong need for employees to develop some skills that may help them emotionally and socially competence in performing their job in the workplace (Ramo, Saris and Boyatzis, 2009). Pfeffer (1981) suggested that political skill is one of the most important skills that will result to the success of organizations. Indeed, he also called for research that would develop more informed on understanding the construct. Ariffin and Maghzi, (2012) mentioned that there is greater impact shows between stakeholders' satisfactions with employees' interaction than any other factors. Furthermore, the focus here is about increasing the stakeholders' positive experience through enhancement on high level of services quality delivered through the interaction process. In the context of the study, stakeholders' here were defined as the customers, suppliers and shareholders within the organization. Thus the objectives of this study are as follows:-

a) To identify whether there is a positive relationship between social astuteness and stakeholders' satisfaction.

b) To identify whether there is a positive relationship between interpersonal influence and stakeholders' satisfaction. 
INTERNATIONAL JOURNAL OF ACADEMIC RESEARCH IN BUSINESS AND SOCIAL SCIENCES

Vol. 10, No. 3, March, 2020, E-ISSN: 2222-6990 @ 2020 HRMARS

c) To identify whether there is a positive relationship between networking ability and stakeholders' satisfaction.

d) To identify whether there is a positive relationship between apparent sincerity and stakeholders' satisfaction.

Mintzberg (1985) viewed organization as inherently a political arena whereby each employee needs to survive in the organization by preparing themselves with the necessary skills and abilities. Interestingly Ferris, Treadway, Perrewé, Brouer, Douglas \& Lux (2007) defined political skill as a comprehensive pattern of social competencies with affective, cognitive and behavioural manifestations, which have direct effects on the outcomes relationships. Furthermore, according to Ferris et al., (2005; 2007), political skill consists of four dimensions which are social astuteness, interpersonal influence, networking ability, and apparent sincerity. Many scholars has proven that political skill was found to be positively related to job performance and team performance in organization (Douglas and Ammeter, 2004; Ahearn et al., 2004; Semadar et al., 2006). Additionally, Rucci et al., (1998) has emphasized the importance of offering quality products or services especially in terms of 'employee-customer-profit chain' in order to gain competitive advantages. This has proved to be one of the important elements in sustaining the organization performance by focusing the firm-customers relationships instead of just focusing on financial performance only. Thus Galbreath (2010) has eloquently stated that firm should show concern on improving the organization performance through the non-financial performances especially embarking into the study of services towards their stakeholders' satisfaction which consists of customers and suppliers of the organization. This study focusses into the political skill of employees within multinational corporation (MNC) and its effect towards the organizational performance since MNC has contributed a lot towards the economy and development of our nation through various investment activities with their stakeholders.

\section{Literature Review}

\section{Political Skill and Stakeholders' Satisfaction}

Two decades ago, political skill were constructed and introduced as a necessary competency that need to be possessed in order to be effective in the organization (Ferris et al., ;1999,2005; Mintzberg, 1983). Political skill also known to be vital in organization as it define that the person or the organization ability to read and understand people or situation around them in order to achieve their goal (Ferris et al., 2005). Such skill has been an important concept in order to career success, work performance and job effectiveness (Ferris et al., 2002; Pfeffer, 1981). There are basically five dimensions of political skill which are social astuteness, networking ability, interpersonal influence and apparent sincerity. Basically, social astuteness define that a person with interpersonal skills which are good at dealing with others, while in the same time perceive others' emotional and motives as well in being sensitive toward others need (Pfeffer, 1992; Ferris, Treadway, Perrewé, Brouer \& Douglas, 2007). Meanwhile networking ability refers to a person's ability in developing ties and relation with others which can be either internal or external ties from their workplace (Ferris et al., $2005,2007)$. Additionally, according to Ferris et al., $(2005,2007)$ a person's that have a strong influence on others especially those in their surrounding are known as ability and characteristics that refers to interpersonal influence individual. Lastly, he also added that apparent sincerity is known as 
INTERNATIONAL JOURNAL OF ACADEMIC RESEARCH IN BUSINESS AND SOCIAL SCIENCES Vol. 10, No. 3, March, 2020, E-ISSN: 2222-6990 @ 2020 HRMARS

the ability to appear to be someone that honest, open and forthright individual. In terms of the stakeholders' satisfaction, it is known as employees, shareholders, customers and suppliers who are considered as an important part of the organization (Henrique \& Sadorsky, 1999). Ferrell (2004) too has mentioned that customers are known as key stakeholders that help to establish the organization identification as well as reputation.

Okpara and Edwin (2015) haves stated there is positive or significant relationship between social astuteness and the organization performances. It defines that social awareness individual able to understand people's thought, nature, vision and perception (Ahuja, 2015). To add more Galbreath (2010) has eloquently stated that stakeholders' satisfaction also known as one of the performances measurement for the organization. To conclude that, the aforementioned statement has shown that: $\mathrm{H} 1$ : Social astuteness has a positive relationship with stakeholders' satisfaction

Meanwhile according to Neshim, Olsen \& Sandvik (2017), they have suggested that networking ability is known to have positive relationship toward the performances. Stakeholders' satisfaction also perceived as performance measurement (Galbreath, 2010). It also indicated that the relationship has shown that a higher networking ability, there is a positive association with organization performance which eventually increases stakeholders' satisfaction. In the nutshell, the aforementioned statement has shown that:

H2: Networking ability has a positive relationship with stakeholders' satisfaction

According to Treadway and his friends (2013), they have suggested that there is positive relationship between high performance and personal power. Personal power can be perceived as interpersonal influence while, performance are known as stakeholders' satisfaction. It shows that there is significant value between the variables thus it can be explain as the higher the organization performances, the higher the organizations' stakeholders satisfaction will be. To summarize, the aforementioned statement has shown that:

H3: Interpersonal influence has a positive relationship with stakeholders' satisfaction

As contested by Brouer et al., (2016) he has proven that apparent sincerity is not significant towards the leader charisma. However, the studies by Yang (2008), he has stated that stakeholder participation in performance measurement is positively associated with honest performance reporting. It indicated that, there is relationship between the variables as; the honest the individual behavior will result to the higher effective performances, therefore it perceived better stakeholders' satisfaction. Individual honesty is indicated as apparent sincerity characteristics. Thus it can be concluded that:

H4: Apparent sincerity has a positive relationship with stakeholders' satisfaction

\section{Research Methodology}

The target populations in this study are represented by the employees within various MNCs in Malaysia. A non-probability sampling specifically judgmental purposive sampling was chosen for this study. This sampling technique is chosen because the researcher are able to identify the sampling units based on their professional judgement (Sekaran \& Bougie, 2013) based on two criteria that has 
INTERNATIONAL JOURNAL OF ACADEMIC RESEARCH IN BUSINESS AND SOCIAL SCIENCES

Vol. 10, No. 3, March, 2020, E-ISSN: 2222-6990 @ 2020 HRMARS

been stipulated. In order to answer this questionnaire, two criterions must be fulfilled by the respondents which are 1) they must be an employee of a multinational corporations (MNC) and 2) their minimum position is executive to the highest level of the head of department. In order to calculate the minimum sample size for this study, G*Power software can best determine the sufficient respondents which is 82 (Faul, Erdfelder, Lang, Buchner, 2007) but this study was able to derive 85 respondents for this study which are adequate for this study.

\section{Findings and Discussions}

\section{Demographic Profile of the Respondents}

The findings has indicated that majority of the respondents are female in with (55.3\%) and aged 36 years old and above. Most of them are married with (61.2\%) with education level of bachelor's degree level (72.9\%). Meanwhile, the majority respondents in has income at RM9,000 each month with (31.8\%). Next, the position level that has most rated at the position of executive management support with (31.8\%). Finally, the working experiences that the respondent has are at 4 years and above with (64.7\%). This study is able to satisfy the convergent, composite and discriminant validity requirements in order to proceed to the structural assessment. The composite reliability for this study ranges between 0.897 till 0.936, meanwhile in AVE ranges from 0.636 to 0.829 with a cut off value of 0.5 (Hair et al., 2014). Meanwhile heterotrait-monotrait (HTMT) ratio of correlations and FornellLarcker's criterion were fulfilled accordingly. Findings of this study has shown that social astuteness (SA) $(\beta=0.104$, $\mathrm{t}$-value $=0.701, \mathrm{p}<0.05)$, followed by networking ability (NA) $(\beta=-0.056$, $\mathrm{t}$-value $=$ $0.422, p<0.05)$ has shown that they are not significantly related. Meanwhile, interpersonal influence (II) $(\beta=0.269$, $\mathrm{t}$-value $=1.681, \mathrm{p}<0.05)$ and apparent sincerity (AS) $(\beta=0.195, \mathrm{t}$-value $=1.730, \mathrm{p}<$ $0.05)$ are significantly related with stakeholders' satisfaction. Additionally it has been indicated that social astuteness, networking ability, interpersonal influence and apparent sincerity were able to explain about $19.6 \%$ of the variance in stakeholders' satisfaction with $R^{2}=(0.196)$ which are consider as average. Meanwhile the values of VIF were below the recommended maximum cut off value of 5 (Cenfetelli \& Bassellier, 2009) thus there is no significance level of collinearity among the exogenous constructs.

\section{Discussion}

In the context of the study, positive relationships between interpersonal influence and apparent sincerity with stakeholders' satisfaction were derived. The findings are consistent with the previous literatures which indicate that political skill has positive impact towards the organizational performance ion (Douglas and Ammeter, 2004; Ahearn et al., 2004; Semadar et al., 2006). Interestingly, the respondents believe that both of this dimensions plays and important roles towards and organization. On the contrary, contradicting findings were achieved in this study in terms of social astuteness and networking ability. It is possible to explain that leaders are usually highly sensitive towards the reactions or needs of employees at the workplace and are able to interpret them correctly according to Brouer et al., (2016); Brouer et al., (2013). In fact, Dulewicz et al., (2003) and Dulewicz \& Higgs (2000) added that managers or leaders in established organization are prone to have a better job performance. Since most of the respondents (31.8\%) are executive management support, it is believed that they are not focusing into being socially astute towards others and also less concern on networks abilities tends to finish any job task given according to their managers and 
INTERNATIONAL JOURNAL OF ACADEMIC RESEARCH IN BUSINESS AND SOCIAL SCIENCES Vol. 10, No. 3, March, 2020, E-ISSN: 2222-6990 @ 2020 HRMARS

leaders instructions. It is also possible to explain that networking ability is not a major concern for the respondents since most of the networking establishments are initiated by the higher levels of management within their companies.

As a conclusion, this study was able to identify roles of political skill towards the stakeholders' satisfaction. In fact, this proved that by possessing interpersonal influence and apparent sincerity among employees, one will be able to satisfy the stakeholders which eventually contribute to a better performing organization. Meanwhile, the relationship between employees' political skill and stakeholders' satisfaction has demonstrated that employees skill can be improve. Keeping in mind that this study is focus on the stakeholders' satisfaction which eventually affects the organizational performance financially and non-financially.Next, the positive relationship of interpersonal influence and apparent sincerity has shown that employer should emphasise on developing the political skill of employees as this will help them to increase their relationships, interaction and communication in the workplace and eventually increasing the satisfaction within and between the stakeholders in the organization.

\section{References}

Ahern, K. K., Ferris, G. R., Hochwarter, W. A., Douglas, C., \& Ammeter, A. P. (2004). Leader Political Skill and Team Performance. Journal of Management, 30: 309-327.

Ariffin, A. A. M., \& Maghzi, A.(2012). A Preliminary Study on Customer Expectations of Hotel Hospitality: Influences of Personal and Hotel Factors. International Journal of Hospitality Management, 31 (1): 191-198.

Cenfetelli, R. T., Bassellier, G. (2009). Interpretation of Formative Measurement in Information System Research. Management Information System Research, MIS Quartely, 33 (4), 689-708.

Chin, W. W., and Dibbern, J. (2007). A permutation based procedure for multigroup PLS analysis: results of tests of differences on simulated data and a cross cultural analysis of the sourcing of information system services between germany and the USA. In: V. Esposito Vinzi, W. Chin, J. Hensler, and H. Wold (Eds.,) Handbook PLS and Marketing. Berlin, Heidelberg, New York: Springer

Douglas, C., \& Ammeter, A. P. (2004). An Examination of Leader Political Skill and its Effect on Ratings of Leader Effectiveness. The Leadership Quarterly, 15: 537-550.

Ferris, G. R., Berkson, H. M., Kaplan, D. M., Gilmore, D. C., Buckley, M. R., Hochwarter, W. A., \& Witt, L. A. (1999). Development and initial validation of the political skill inventory. Paper presented at the Academy of Management, 59th Annual National Meeting, Chicago

Ferris, G. R., Darren, C. Treadway, D. C., Pamela, L., Perrewé, P. L., Robyn, L., Brouer, R. L., Ceasar Douglas, C., \& and Lux, S. (2007). Political Skill in Organization. Journal of Management, 33 (3), : pp. 290-320.

Ferris, G. R., Darren, C., Treadway, D. C., Robert, W., Kolodinsky, R. W., Wayne, A., Hochwarter, W. A., Charles, J., Kacmar, C. J., Douglas, C., \& and Dwight, D., Frink, D. D. (2005). Development and Validation of the Political Skill Inventory. Journal of Management, 33 (1), : pp. 126-152.

Fornell, C. G., \& Larcker, D. F. (1981). Evaluating structural equation models with unobservable variables and measurement error. Journal of Marketing Research, 18(1), 39-50. 
INTERNATIONAL JOURNAL OF ACADEMIC RESEARCH IN BUSINESS AND SOCIAL SCIENCES

Vol. 10, No. 3, March, 2020, E-ISSN: 2222-6990 C 2020 HRMARS

Galbreath, J. (2010). The Benefits of Corporate Social Responsibility: An Empirical Study. Graduate School of Business, Curtin University of Technology, Perth, Australia.

Hair, Jr, J. F., Sarstedt, M., Hopkins, L., Kuppelwieser, V. G. (2014). Partial least squares structural equation modeling (PLS-SEM): An emerging tool in business research. European Business Review, 26 ( 2),106-121.

Mintzberg, H. (1983). Power in and around organizations. Englewood Cliffs, NJ: Prentice Hall.

Mintzberg, H. (1985). The Organization as a Political Arena. Journal of Management Studies, 22: 133154.

Pfeffer, J., Faul, F., Erdfelder, E., Lang, A. G., Buchner, A. (2007). G*Power 3: A Flexible Statistical Power Analysis Program For The Social, Behavioral, And Biomedical Sciences. Articles From the SCiP Conference: 39 (2). (1981). Power in Organizations. Boston: Pitman.

Ramo, L. G., Saris, W. E., \& Boyatzis, R. E. (2009). The Impact of Social and Emotional Competencies on Effectiveness of Spanish Executive. Journal of Management Development, 28 (9), 771-793.

Rucci, A. J., Kirn, S. P., \& Quinn, R. T. (1998). The Employee - Customer Profit Chain at Sears. Article in Harvard Business Review. 76 (1).

Sekaran, U., and Bougie, R. (2013) Research Methods for Business: A Skill-Building Approach. 6th Edition, Wiley, New York.

Semadar, A., Robins, G., \& Ferris, G. R. (2006). Comparing the Effects of Multiple Social Effectiveness Constructs in the Prediction of Managerial Performance. Journal of O Galbreath, J., (2010). The Benefits of Corporate Social Responsibility: An Empirical Study. Graduate School of Business, Curtin University of Technology, Perth, Australia. 